\title{
TETDMを用いた電子カルテ分析支援ツールの開 発と実カルテ分析での検証
}

\section{Development of EMR Analysis Support Tool based on TETDM and Its Evalua- tion through Actual EMR Analysis}

\author{
高間 康史首都大学東京大学院システムデザイン研究科 \\ Yasufumi Takama Graduate School of System Design, Tokyo Metropolitan University \\ ytakama@tmu.ac.jp \\ 串間 宗夫 \\ 宮崎大学医学部附属病院医療情報部 \\ Medical Informatics, University of Miyazaki Hospital \\ muneo_kushima@med.miyazaki-u.ac.jp \\ 砂山 渡 \\ 広島市立大学大学院情報科学研究科 \\ Graduate School of Information Sciences, Hiroshima City University \\ sunayama@hiroshima-cu.ac.jp
}

keywords: text mining, EMR, TETDM, exploratory data analysis.

\section{Summary}

This paper proposes an analysis support tool for EMR (electronic medical record), based on which examines its applicability to EMR analysis task in a hospital. As the spread of EMR into hospitals, the demand for analyzing EMR for improving quality of medical care as well as for contributing to hospital management is increasing. Although application of data mining techniques is promising, it has not been so popular today. The proposed tool consists of two sub-tools: a tool for analyzing EMR with visualization, and that for adding technical terms to a dictionary used by a morphological analyzer. Those are developed on TETDM (Total Environment for Text Data Mining), which makes it possible for users to use multiple tools through unified interface. In order to examine the applicability of the proposed tools and TETDM to EMR analysis in a hospital, doctors and nurses in a hospital used the tool for analyzing actual EMR. The experimental result shows that they can analyze the difference between EMR written by novice nurses and veteran. It is also shown adding technical terms extracted from EMR is useful for improving the quality of text processing as well as for reducing ambiguity of terms.

\section{1. は じめに}

本論文では ,テキストデータマイニング統合環境TETDM (Total Environment for Text Data Mining)[砂山 11, 砂山 13, 砂山 14] を利用した電子カルテ分析支援ツールを提 案し, 病院での電子カルテ分析作業への適用可能性につ いて検証する .

電子カルテは医師による診療記録や看護師による看護 記録などから構成され，医療・看護の継続性や，医療従 事者と患者間での診療情報共有に繋がる重要な文書であ る [厚労省 05] . 近年では診断などの日常業務における活 用だけでなく，医療の質向上 [土井 09, 川中 05, 岡垣 11] や病院経営への活用 [紀ノ定 03, 山崎 13] などを目的とし た二次利用も視野に入れられており，データマイニング 技術の活用が期待されているが，現状ではまだ試行の段 階といえる [村松 10].

本論文では, 看護師により記載された電子カルテ (看
護記録) を分析対象とする . 看護記録の監査は, 患者に 提供されたケアの質を明らかにするために必要不可欠で あり，監査を定期的に行い，光の結果に基づき記録の質 を向上させることが, 看護の質向上において重要である ことが指摘されている [東 05, 元永 09]. 本論文でデー 夕提供，実験協力をしていただいた病院 (約 600 床) で は, 医師, 看護師による記録が日に 2,000 件程度発生す る .この内 , 医師が作成する退院時サマリについては 2 名の診療情報管理士が全件目視で監査しているが, 一日 あたり 5 時間程度の時間を要している . 看護記録の監査 については, 人的・時間的コストの関係上, 現状では抽出 法による監査にとどまっている . 具体的には , 年間 2-4 件の入院患者をランダムに抽出し，期間を限定した上で， 弚の間に作成された看護記録のみを監査している．従っ て，テキストマイニングにより電子カルテを分析し，医 療従事者の負担を軽減することが期待されている．

テキストマイニングによる看護記録分析に期待される 
効果としては, 看護記録監査表の改善, 記載の質向上に 向けた対策立案，監査作業の支援あるいは自動化があげ られる．看護記録の監査について，現状では各病院にお いて独自の監査表を用意し，これに基づき監査を行って いる [東 05, 元永 09] . 例えば東らは, 誤字・脱字がない か , 実施入力の漏れがないかなどの 13 項目のチェックポ イントを定め，各項目について「十分／不十分」の二択 で評価を行っている [東 05] . 実験に協力していただいた 病院でも同樣の監查表を病院独自で作成し，監査に利用 している.監査表は過去に 3 回改訂を行っているが, 定 期的に見直し，改善する必要性を感じているとのことで あり, テキストマイニングによる分析結果を活用するこ とが期待できる。

看護記録の記載の質向上に向けた取り組みとして，協 カしていただいた病院における現状では監査結果を記録 者 (看護師) 本人にフィードバックしているが , 全件監 査でない以上, 対象となる看護師は一部となるため, 光 の改善効果は限定的となっている.より多数の看護記録 を対象として分析した結果に基づき, 記入フォームの改 善や , カルテ作成の教育プログラムの検討などを行うこ とができれば，組織的なレベルでの質向上に向けた取り 組みが可能になることが期待できる．さらに，監査記録 の質に関する客観的評価指標を確立することができれば， 監査自体の自動化や監査作業支援インタフェースの開発 なども，将来的に期待できると考える．

本論文では第一段階として, テキストマイニングを適 用することで記述品質管理や看護師の指導への応用など に有益な知見か得られるかどうかを検証対象とする.デー タ分析の方針として, 新人看護師とベテラン看護師によ る記述の違いに着目する．比較は探索的分析で一般に用 いられる戦略であり [高間 11] , データ分析に必ずしも慣 れていない医療従事者でも作業がしやすいと考える . ま た，現状では各病院で独自に監査表を作成している樣に， 病院あるいは診療科によって記述内容や語彙に違いがあ ると考えられる．乥こで，辞書整備などによる分析環境 のカスタマイズも考慮する.

提案する電子カルテ分析支援ツールは, 電子カルテか ら抽出したキーワードを可視化することでカルテの特徽 分析作業を支援するツール [谷 13] , および辞書構築支 援ツール [高間 13] から構成される.辞書構築支援ツー ルでは , 分析対象の電子カルテ集合から専門用語候補と なる複合名詞を抽出・提示し, 利用者がインタラクティ ブに辞書へ追加可能とする .これらのツールの開発には TETDM を用いる. TETDM は, テキストマイニング研 究者によるツール開発・公開を容易にすること, ツール 開発者と利用者の出会いの場を提供することで, 研究成 果の現場へのフィードバックや，現場からのニーズ獲得 を促進することなどを使命として開発が進められている． 利用者のニーズと開発者のシーズのマッチングが有効に 期待できる分野として，TETDM の開発プロジェクトで
は当初から医療現場への応用を検討しており[砂山 13]， 本論文は光の実践に関する初の試みとなる．

開発したツールを実際の電子カルテに適用し，医師お よび看護師に , 看護師の熟練度による電子カルテの記述 の違いについて分析を行ってもらった .ツールの利用状 況の分析や, 分析結果を元に得られた知見, ツール利用 に関する医師・看護師からの意見などに基づき，提案ツー ル及び TETDM の医療現場への適用可能性について考察 する .

\section{2. 関 連 研 究}

\section{$2 \cdot 1$ 電子カルテ分析}

医療情報システムは，外来患者への請求処理を扱う医 事会計システム, 複数の自動分析装置を総合的に制御す る検査部門システム , 検査依頼などのオータ情報を部門 システムへ受け渡すオーダエントリーシステム, 診療記 録などを管理する電子カルテシステムなどから構成され る [松村 12] . 医事会計システムの導入が 1960 年代と最 も早く, 弚の後オーダエントリシステムが 1980 年代は じめから導入されている [松村 01] . 電子カルテシステム の導入は 1990 年代後半から始まり，1999 年には厚生労 働省か診療記録の電子媒体による保存の原則を定めるな ど，電子カルテシステムの普及が進んでいる．電子カル テに記載されるべき情報としては, 以下の樣な情報が挙 げられる [松村 01] .

・医師が記入する情報：初診時の記録，経過記録，退 院時サマリ, 病名

・看護師が記入する情報：観察記録，看護記録

電子カルテ導入がもたらす病院組織の変化についての 分析もなされており，アンケートによる調査および因子 分析やパス解析などにより，電子カルテがもたらす新た な機能が可視化であること，乥れが個人の意識に影響を 与え, 正確性の向上や患者サービスといった面での変化 を経由して組織の変化に繋がることか報告されている[高 橋 07] .

電子カルテ導入のメリットは, 上記のような日常業務 に与えるものだけでなく，電子カルテにより管理される 診療情報や管理情報の二次利用も期待されており，医療 情報学分野の重要研究課題に位置づけられている[紀ノ 定 06].

二次利用に関して , データ分析のための仕組みは日常 の定常業務から切り離すべきであり，データウェアハウ スを別途構築することが行われている [松村 01] . 山本ら は日常診療情報を逐次データベース化し，疾患の予後・ 予後因子・治療成績・医療技術の安全性などを評価する臨 床研究用データウェアハウスを構築している [山本 07] . 電子カルテを二次利用し連携することによる臨床研究の 効率化・コス卜削減の可能性を示している. 
電子カルテに集積されたデータの分析目的として，医 療の質向上 [土井 09, 川中 05, 岡垣 11] や , 病院経営への 活用 [紀ノ定 03, 山崎 13] が挙げられる . また , データ の二次利用に有効であることが期待される技術の一つに データマイニングが挙げられている．

病院経営に関して, 山崎らは, 医療プロセスや投入し た医療資源に何らかの問題があり，収支的に大きくマイ ナスを示した症例を含む教育用電子カルテを作成し，症 例経営分析の教育プログラムを実施している [山崎 13] . 紀ノ定は, 診療の工程管理にプロジェクトマネジメント の考え方を導入し，実施した診療工程を定量的に評価す るシステムの構築が不可欠であると指摘し，PDCA サイ クルの Actionに相当する診療成果・工程の改善行動に有 効な技術の一つとしてデータマイニングを挙げている[紀 ノ定 03].

医療の質向上に関して, 土井らは退院時サマリーにテ キストマイニングを適用し, 病院間での単語構成の比較 を行った他, ベクトル空間モデルによるサマリー間の類 似度に基づく DPC (Diagnosis Procedure Combination , 診断群分類) 判定の可能性について実験を行っている [土 井 09] . 岡垣らは, カード型電子カルテインタフェースを 開発し, 病院に導入しており，インタフェースが電子カ ルテの記載の質や診療内容にどのような影響を与えるか について，時間外外来における実際のカルテデータを分 析している [岡垣 11]. 兴の結果, 記載文字数, 記載率の 点でカード型インタフェースは従来のロールペーパー方 式よりも優れており，診療内容に関してもカード型の方 が高い評価が得られたことを示している．川中らは，イ ンシデント報告における自由書式で記入された部分を対 象として，キーワードを抽出し，SOMにより可視化して いる [川中 05] . 形態素解析を適用したキーワード抽出に おける問題点として，一単語として認識されるべきもの が分割される過分割などがあり，辞書整備の必要性を指 摘している.

\section{$2 \cdot 2$ 専問用語抽出}

テキストマイニングの前処理に形態素解析を利用する 場合，意味のある単位で語を抽出できること，品詞情報 が利用できることなどの利点があるが , 辞書に登録され ていない単語は正しく抽出できないという欠点がある． 弚のため, 分析対象ドメインにおいて使われる専門用語 などを辞書に追加することがしばしば行われる . 専門用 語辞書が整備されていないドメインでは，対象文書集合 などから専門用語を抽出し，辞書に追加する必要がある．

専門用語候補を抽出する手法は, 品詞パターンを利用 するアプローチ [小山 06, 林 08] と，コーパス内での出 現頻度や連接コストなどの統計情報を利用するアプロー チ [中川 03, 湯本 01 , 辻河 04 , 相澤 05 , 上村 07] に大別さ れる．いずれも，専門用語の多くは全くの新規語ではな く，既存の単名詞の組み合わせで形成されていることを
想定している . 品詞パターンを利用するアプローチでは， 複合語を構成する品詞の組み合わせに着目する，林らは， スニペットの代替となるような特徵語の抽出を目的とし て，スペースを含まず連続して抽出された名詞，未知語， 英単語, 数詞などからなる複合語を特徵語候補としてい る [林 08] . 小山らは, 非語/非用語を抽出してしまう有害 な品詞パターンについて提案している[小山 06] .

コーパス内の統計情報を利用するアプローチで代表的 なものにLR，C-value があり，弚れ午れ次式で表される スコアを用いて専門用語候補を抽出する [中川 03, 湯本 01] . 両方とも , スコアが高いほど尃門用語候補としてふ心 さわしいと判断する .

$$
\begin{aligned}
& \text { Cvalue }(w)=\left(L_{w}-1\right)\left(\operatorname{df}(w)-\frac{\mathrm{t}(w)}{\mathrm{c}(w)}\right) \\
& \operatorname{LR}(w)=\sqrt{\prod_{i=1}^{L_{w}}\left(\operatorname{LN}\left(n_{i}\right)+1\right)\left(\operatorname{RN}\left(n_{i}\right)+1\right)}
\end{aligned}
$$

ここで, $w$ は $L_{w}$ 個の単名詞 $\left(n_{i}\right)$ で構成される複合 名詞, $\mathrm{df}(w)$ はコーパス中の出現頻度, $\mathrm{t}(w), \mathrm{c}(w)$ は光

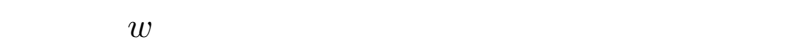
$\mathrm{LN}(n), \mathrm{RN}(n)$ は $n$ が光れ艺れ右側，左側に来る単名詞 バイグラムのコーパス中出現頻度を表す. 単名詞にも対 応するようにC-value を拡張した MC-value[中川 03] , w の出現回数を考慮するために, $w$ の単独出現頻度と LR の積で定義される FLR[湯本 01] も提案されている.性 質の違いに関して比較実験を行った結果もいくつか報告 されており，LRによるスコア上位は複合名詞が多いが， FLR, MC-value では単名詞が多いなどの実験結果が報告 されている [湯本 01] . LR や FLR は単名詞の連接コス 卜を考慮した手法であるが， HITS や PageRank を利用 した手法も提案されており [辻河 04]，LRよりも大局的 な指標であることが示されている．この他，土木関連用 語を対象として, 品詞パターンベースと連接ベースのア プローチを組み合わせた手法 [相澤 05] も提案されてい る.また，専門用語は対象分野以外のコーパスにはあま り多く出現しない，という特徵に着目し，他の専門分野 のコーパスにおける出現率と比較して抽出する手法も提 案されている[久保 10] 。

\subsection{TETDM: Total Environment for Text Data Min- ing}

本節では，TETDM 統合環境について述べる．TETDM は，あるテキストを入力したときに，产の分析処理を行 うマイニング処理モジュールと，処理結果を可視化して 出力する可視化モジュールを複数備えた環境となってい る．またこれらのモジュール群は, 単独の開発者によっ て提供されるものではなく，任意の開発者がモジュール を作成して利用することができる．

TETDM では，独立した複数のパネル内に，マイニン グ処理モジュールと可視化モジュールを1つずつペアと 
してセットすることで動作する . 各パネルにセットされ る，異なる開発者によって作成されたモジュールが，光れ 光れ独立に動作するだけではなく，光れらを協調的に連 動させることができる点がTETDM の特徵となっている .

TETDM はライトウェイトなツールを提供するプラッ トフォームに位置づけられる.データ分析作業を本格的か つ定常的に行うことが決定しているような場合には，商 用の高機能·高価なツールの導入も検討に值するが , 本論 文のように有効な分析方法も定まっておらず,試験的に分 析を行う段階には，TETDM の適用が適していると考え る・また ,UIMA (Unstructured Information Management Architecture) [Ferrucci04] に準拠した統合言語処理環境 もいくつか開発されているが [狩野 08, 狩野 12], 乥れらは テキスト解析処理の組み合わせやワークフロー形成に焦点 があるのに対し，TETDM ではツールレベルの組み合わせ に焦点がある.利用するツールを選択し，パネルにセット して用いるため, 利用者の観点からは GUI を自分で構成 するイメージとなる . 情報可視化システムの構成としては Coordinated Multiple Views (CMV) [Andrienko07] に該 当し, 異なるビュー間の連動が重要となるが，TETDM で は後述するフォーカス連動などにより, 異なる開発者が 別々に開発したツール間でも，ビュ一間連動の実現が容 易となっている．テキスト処理の組み合わせをツール利 用者が変更することは困難であるが, 利用者はより上位 な, ツールレベルでの組み合わせに専念できるため， テ キスト分析処理に詳しくないユーザでも利用しやすいも のとなっており，本論文で対象とする問題に適している と考える。

$\S 1$ 入カ: テキスト

TETDM に入力されたテキストは「セグメント」「文」 「単語」の 3 つに分割して扱われる.「単語」へ区切る際 は, 形態素解析器を用いて単語に分割する.この際, 指 定した品詞の単語だけを，キーワードとして取り扱う． 「文」に区切る方法は, テキスト中の句点記号（「。」や 「」)をもとに分割する、セグメント」に区切る方法は， 特定の文字列をテキスト中に挿入し，弚の文字列をもと に分割する. 兴の後, 単語の出現情報や頻度情報の計算, キーワードやセグメント間の関連度計算を行った結果を データ構造に格納し，これをもとに各モジュールが処理 を行う.

$\S 2$ マイニング処理モジュール

マイニング処理モジュールは, 統合環境内のテキスト データをもとに, テキストの理解や分析に役立つ情報を テキストから抽出する . またマイニングという言葉にこ だわることなく,テキストに何らかの処理を施すモジュー ルも対象とする. 2014 年 1 月 24 日現在までに 30 以上の マイニング処理モジュールが作成, 公開されている.マ イニング処理モジュールの処理結果は, 可視化モジュー ルに渡されて出力される．
$\S 3$ 出力：可視化モジュール

可視化モジュールは，マイニング処理モジュールによ る出力結果を可視化する*1. 可視化モジュールでは, 入力 として受け取れるデータ型 (boolean, int, double, String 型と光の一次元配列, 二次元配列 (String 型以外) の 11 種類) を定め, 光のデータの意味を表す整数型変数との 組合せにより，マイニング処理モジュールからデータを 受け取ることができる. 現在までに 30 以上の可視化モ ジュールが作成, 公開されている.

$\S 4$ テキスト分析に向けた機能

テキスト分析に向けた機能として，「フォーカス連動」 と「部分テキストに対する処理」が挙げられ，本論文で も利用している。

フォーカス連動とは, ユーザが着目したデータ (マウス て触れる，あるいはクリックしたデータ) を観点として， 各モジュールがハイライト等の処理を行う機能となって おり，ブラッシング (brushing) の実装に用いられる.す なわち，独立して開発された異なるモジュール上で, 対 応するデータを明示的に確認することができる．

また , 入力されたテキスト全体に対する結果だけでは なく，一部のテキストに対する結果を出力する機能があ る. 光のため, 入力されたテキスト内で複数の部分テキ ストを作成し，乥れら部分テキスト間の比較を行うこと ができる .

\section{3. 電子カルテ分析支援ツール}

\section{$3 \cdot 1$ ッールの構成}

医師や看護師による電子カルテの分析作業を支援する ツールを TETDM を用いて開発した . $2 \cdot 1$ 節でも述べた 樣に, 電子カルテの解析においては形態素解析に利用す る辞書の整備が重要であることか指摘されている．また， 実際の医療現場では, 病院毎に特有の単語や言い回しな どが利用されることも想定される. 弚のような場合, 既 存の専門用語辞書を利用するよりも，2.2 節で述べた手 法により，対象文書から専門用語候補を抽出する事か効 果的と考える. 弚こで本論文では, 電子カルテの分析支 援だけでなく, 対象電子カルテから専門用語候補を抽出 し，辞書に追加する作業の支援も対象とする．このため， 電子カルテ分析支援ツール (3.2 節) [谷 13], 辞書構築支 援ツール (3.3 節) [高間 13] を光れ複数のパネルを 組み合わせて実装し，作業時には TETDM のパネルセッ 卜機能を用いて両ツールが表示された状態（後述する図 1 と図 4) が切り替わるようにしている.

TETDM を用いて開発する利点として,ツール利用者に 統一的なインタフェースを提供できることが挙げられる． 今回のように複数の異なる作業を支援する場合 , 異なる インタフェースを持つ別々のツールとして開発されたので

*1 マイニング処理モジュールの結果によらず , 統合環境のテキ ストデータを可視化するモジュールであっても良い. 


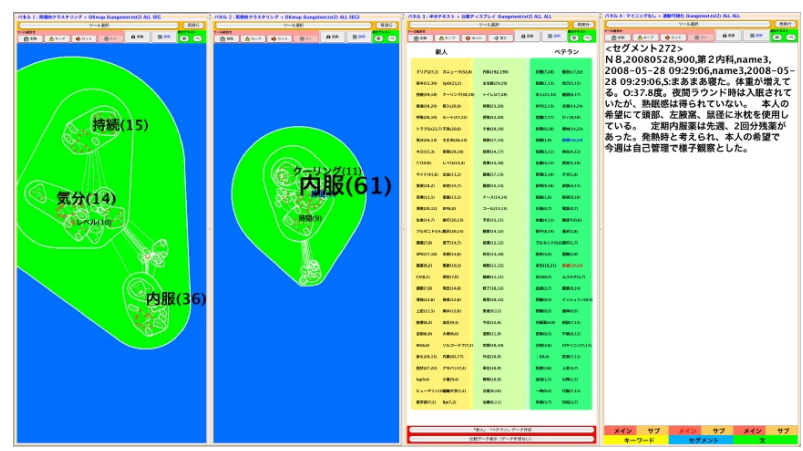

図 1 電子カルテ分析支援ツールのスクリーンショット

は, 利用者側は両ツールの利用設定, 使い方の習得が必要 になる．また，すべての機能を持つ一つのツールとして開 発した場合，スクリーン内に多数の情報や操作メニュー・ ボタンが一度に表示されると，利用者にとっての利便性 は低下すると考える．これらの問題に対し，TETDM で はツールの利用設定は一括して行える他 , 個々のツール 特有の処理以外のインタフェースは共通化されていると いう利点がある .さらに , パネルの組み合わせを記憶し， 一括して表示を切り替える機能により，一度に表示する 情報や機能を制限することが可能である．

\section{$3 \cdot 2$ 電子カルテ分析支援ツール}

電子カルテ分析支援ツール (図 1) は, 以下の 4 つのパ ネルから構成されている(括弧内に, 各パネルにセット されているマイニング処理モジュールと可視化モジュー ルを記す）．

1.新人のカルテマップ（「再帰的クラスタリング」+ $\ulcorner\mathrm{OKmap}\lrcorner)$

2.ベテランのカルテマップ (「再帰的クラスタリング」+ $\ulcorner$ OKmap $\lrcorner$ )

3.新人とベテランの単語比較パネル (「半分テキスト $」+$ 「比較ディスプレイ」)

4.電子カルテ表示パネル (「マイニングなし」+「連動 可視化」)


再帰的クラスタリング [砂山 12]により分類し，乥の結 果を地図状に表示する．地図内では，マウス操作によっ て拡大 , 縮小 , 平行移動を行うことができる.地図内の 各クラスタには, 各クラスタ内の最も多くのカルテ内で 使用されている単語がラベルとしてつけられ，弚のカル テ数が数值として表示される.地図内の各ノードは, 個 別のカルテを表し, 弚のカルテ内で最も頻度が高い単語 がラベルとしてつけられる .

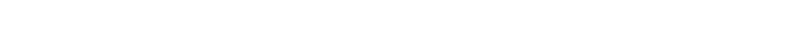
ている単語をもとに, 新人とベテランが同程度に使用し ている単語を中央に, 新人がよく使う単語を左側に, ベ テランがよく使う単語を右側に配置している . 具体的に は, 各単語について ,(新人が使っているカルテ数 -ベテ

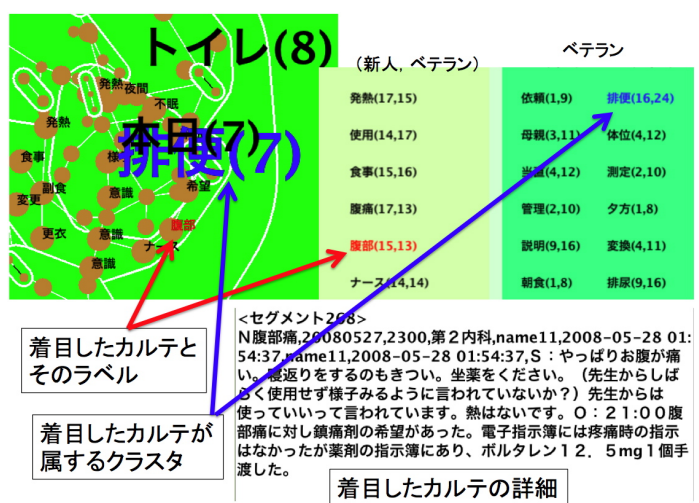

図 2 電子カルテ分析支援ツールを利用した分析のイメージ (左 上「OKmap」，右上「比較ディスプレイ」，下「連動可視化」 から光れ光れ抜粋)

ランが使っているカルテ数) を計算し，正の值が大きい 単語を順に新人の領域に，負の值が小さい単語を順にべ テランの領域に，絶対値が小さい単語を順に中央の領域 に配置する．また，左のいずれかの地図内でカルテにマ ウスカーソルがあてられた際には, 弚のカルテのラベル を青色で , 弚のカルテを含むクラスタのラベルを赤色で ハイライトする .

一番右のパネルでは, 左のいずれかの地図内でカルテ にマウスカーソルがあてられた際に , 产のカルテの内容 を表示する .

これら 4 つのパネルを利用して , 新人のカルテ集合と ベテランのカルテ集合の比較を促す . 比較のためには， 新人またはべテランのカルテにはどのようなものが多い かを弚れ認識する必要があり，左の地図内でクラス タリングされたカルテ集合を比較することや，弚れ光れ のカルテ集合で使われている単語の傾向を調べることに よって比較分析を行う.

電子カルテ分析支援ツール内で利用した 3 つの可視化 モジュールは，乥れ午れが最初から電子カルテの分析を 目的として用意されたものではない. 3 つの別々の用途 で用意されたモジュールを組み合わせて利用することで， 電子カルテに関する複数の情報を視覚的に確認できる環 境を整えている．すなわち，新人またはべテランの電子 カルテを分類する際に有効な単語を OKmap モジュール で確認した際に，弚の単語が新人とベテランのどちらが より使う傾向にあるかを，比較ディスプレイモジュール で即座に確認できるとともに，光のカルテの詳細を連動 可視化モジュールで確認できる (図 2) .なお，図 2 中の 比較ディスプレイのスクリーンショットにおける, 各単 語の右側に記されている数值は, 右側が光の単語を使用 しているべテランカルテ数, 左側が新人カルテ数である . 


\section{$3 \cdot 3$ 辞書構築支援ツール}

提案する辞書構築支援ツールのモジュール構成を図 3 に示す . ツールは二つのパネルから構成され , 一つはマ イニング処理モジュール TermExtraction と可視化モジ ュール TermDisplay , 他方はマイニング処理モジュール TermHighlight と可視化モジュール TextDisplayHtml から それ光れ構成される.図4にTETDMを用いて実装したプ ロトタイプのスクリーンショットを示す . TermExtraction と TermDisplay を組み合わせたパネルは複数同時表示す ることが可能であり，図 3 では左側 2 枚がTermDisplay， 右側 1 枚が TextDisplayHtml のパネルに艺れ光れ対応 する。

TermExtraction モジュールは , $2 \cdot 2$ 節で述べた専門用 語抽出手法を実装し , スコアの上位 150 語を降順にソー 卜した専門用語候補のリストを TermDisplay モジュール に送る . ツール利用者は, TermDisplay モジュール上に 表示された候補語を見ながら，光れが専門用語として適 切か否か (あるいは, 一単語として扱うことが分析にお いて有効か）を選択できる . 候補語上でダブルクリック するたびに, 状態が正解語・不正解語・未チェックの順 に変化するようになっており，下部にあるUpdateDic ボ タンを押すことによって, 正解語が TETDM の単語辞書 に追加され，以降のテキスト読み込み時に反映される . なお，単語の追加はパネルごとに独立しており，光れ光 れのパネル内でUpdateDic ボタンを押す必要がある . ま た， ResetDic ボタンを押すことにより辞書が初期状態に リセットされる .

TermExtraction モジュールは, 各種専門用語抽出アル ゴリズムを実装し，差し替えて利用可能とするため, ベー スとなるモジュール (クラス) として TermMiningBase を開発した .このモジュールは TermDisplay との連動に 関する処理のみを実装したものであり，TermExtraction モジュールはこれを継承することで開発する.本論文では C-value,FLR を TermExtraction モジュールとして実装し， 図 3 ではとれ光れ左と中央のパネルにセットしている .

TermHighlight モジュールは , TermDisplay モジュール 上でシングルクリックされた候補語のカルテ中での出現 箇所をハイライトし，谷の結果を HTML ソースとして TextDisplayHtml モジュールに送る . TextDisplayHtml モ ジュールは HTML ソースを表示するモジュールであり， TETDM に標準で付属する . TermDisplay と TermHighlight 間の連携は, $2 \cdot 3 \cdot 4$ 節で述べたフォーカス連動機能 を利用して実装している。

\section{4. 評 価 実 験}

\section{$4 \cdot 1$ 実 験 概 要}

生の電子カルテは個人情報を含んでいるため, 解析し て活用する上では、個人を特定できないようにする必要 がある．本論文では，実際に匿名化を行った内科診療科

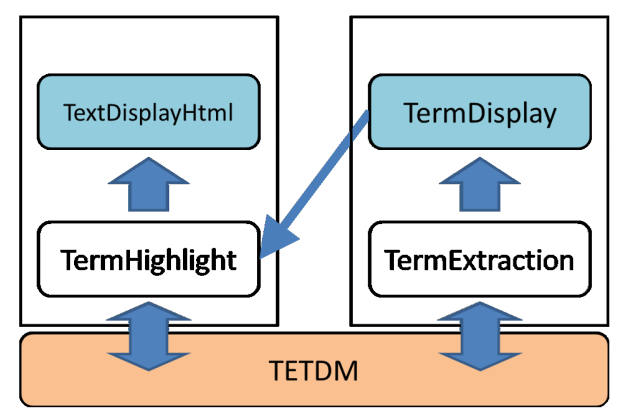

図 3 辞書構筑支援ツールのモジュール構成

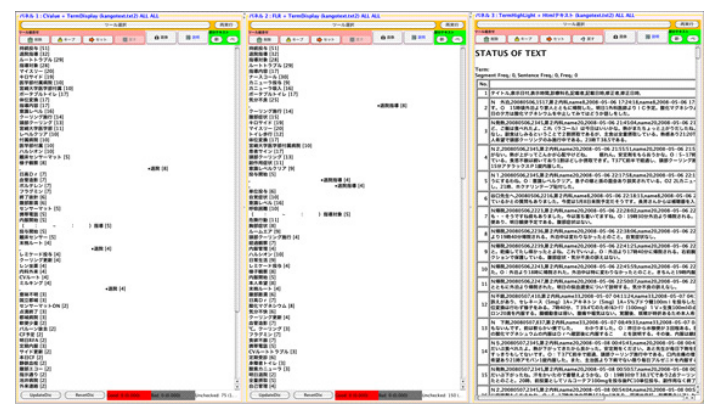

図 4 辞書構築支援ツールのスクリーンショット

電子カルテ入院患者看護記録テキストデータを用いて評 価実験を行った . 看護師 23 名が作成した 382 件の電子力 ルテについて , 提案する電子カルテ分析ツールを用いて 分析を行い, 新人 (経験年数 3 年以下) とベテラン (経 験年数 6 年以上) でカルテの書き方にどのような違いが あるかを検討してもらった . 新人 , ベテランの定義は組 織にもよると考えられるが, データ提供者である医療従 事者に事前に確認してもらった結果, 経験年数 3 年以下 と光れ以降で記述内容が明らかに異なる傾向が見られた ため, 3 年以下を新人とした . また , ベテランに関して は，新人とデータ量が同程度となるように，経験年数の 多い看護師から選択している．図５に，各看護師の経験 年数およびカルテの件数を示す. 赤丸が新人 , 青丸がべ テランのデータである . TETDM による形態素解析の結 果，新人データは 1,236 文，キーワード 1,061 語 , ベテ ランデータは 1,081 文, キーワード数 1,138 語であった . 表 1 に示す 8 名の医師あるいは看護師に協力を依頼し， 以下の手順で作業を行ってもらった .

(1) 電子カルテ分析支援ツールを用いて電子カルテを 分析

(2) 辞書構築支援ツールを用いて分析に有用と思われ る単語を追加

(3) ステップ 2 で更新した辞書を利用し，ステップ 1 を再度行う。

ステップ 1 , 3 では, 新人, ベテランが記入したカル テ炎れ午れの特徵及び, 両者の違いを回答してもらった . また, 弚の際に着目した単語がある場合には光れも回答 してもらった . 作業時間は, ステップ 1 が平均 30 分 (標 


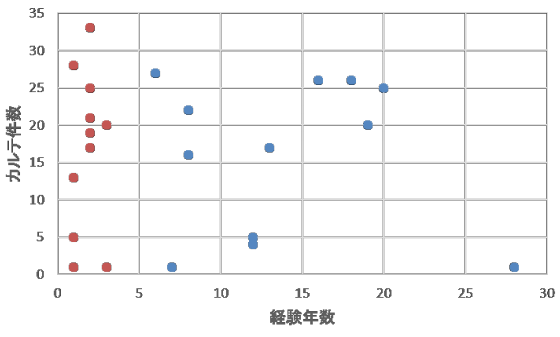

図 5 看護師毎の経験年数とカルテ件数

表 1 実験協力者の概要

\begin{tabular}{|c|l|}
\hline 協力者 & 職種他 \\
\hline $\mathrm{A}$ & 医師 (心藏外科) \\
\hline $\mathrm{B}$ & 医師 (解剖学) \\
\hline $\mathrm{C}$ & 看護師 (若手) \\
\hline $\mathrm{D}$ & 看護師 (管理室) \\
\hline $\mathrm{E}$ & 看護師 (若手) \\
\hline $\mathrm{F}$ & 看護師 (外来) \\
\hline $\mathrm{G}$ & 看護師 (情報管理室) \\
\hline $\mathrm{H}$ & 医師 (血液内科) \\
\hline
\end{tabular}

準偏差 4 分), ステップ 2 が平均 23 分（標準偏差 7 分）, ステップ 3 が平均 24 分 (標準偏差 2 分) であった .

以降, 辞書構築支援ツール, 電子カルテ分析支援ツー ルに関する実験結果弚れ光れについて示した後, ツール の利用に関する実験協力者の評価についてまとめる .

\section{$4 \cdot 2$ 辞書構築支援ツールの評価}

$3 \cdot 3$ 節で述べた通り，開発したツールではスコア上位 150 語を提示することにしているが, C-value はスコアが 0 より大きい 75 語のみを提示した . FLR ではスコアが 0 より大きい候補語は 480 語あつたが，光のうち上位 150 語力提示されている.表 2 に, 両手法による上位 15 語を， 表 3 に, 各実験協力者が辞書に登録した単語数を乥れ光 れ示す.表中，CValue，FLR は，当該手法のみで提示さ れた候補語，Both は両手法で提示された候補語の登録数 であり，Total は各協力者が登録した単語の総数である． 全協力者で, FLR から追加された単語のほうがC-value よりも多くなっているが, FLR の抽出単語数が多いこと が光の原因といえる.図 6 , 図 7 に, 候補語の順位と辞 書追加件数の関係を示す . 上位 30 語では C-value の登録 単語数が 4-26 語, FLR が 6-22 語, 上位 50 語では光れ

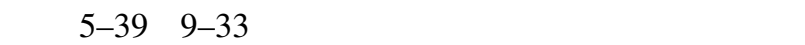
らの登録単語数では光れほど差がないことがわかる．抽 出単語の専門用語としての適切さではなく, 電子カルテ の分析作業における効果の観点から辞書構築支援ツール の有効性を考えた場合，客観的な評価指標の一つとして 登録単語数が考えられる．すなわち，着目単語として有 効であったり，再帰的クラスタリングにおいて分析者に
表 2 専門用語候補上位 15 語の比較

\begin{tabular}{|c|c|c|}
\hline 順位 & C-value & FLR \\
\hline 1 & 持続投与 & 持続投与 \\
\hline 2 & 退院指導 & 退院指導 \\
\hline 3 & ルートトラブル & 指導対象 \\
\hline 4 & 指導対象 & ルートトラブル \\
\hline 5 & マイスリー & 指導内容 \\
\hline 6 & キロサイド & ナースコール \\
\hline 7 & 医学部付属病院 & カニューラ投与 \\
\hline 8 & 宮崎大学医学部付属 & カニューラ吸入 \\
\hline 9 & ポータブルトイレ & ポータブルトイレ \\
\hline 10 & 指導内容 & 気分不良 \\
\hline 11 & 体位変換 & ロ退院指導 $* 2$ \\
\hline 12 & 意識レベル & クーリング施行 \\
\hline 13 & クーリング施行 & 腹部症状 \\
\hline 14 & 頭部クーリング & キロサイド \\
\hline 15 & 宮崎大学医学部 & マイスリー \\
\hline
\end{tabular}

表 3 登録単語数の比較

\begin{tabular}{|c|c|c|c|c|}
\hline 協力者 & C-value & FLR & Both & Total \\
\hline A & 12 & 40 & 20 & 72 \\
\hline B & 9 & 35 & 16 & 60 \\
\hline C & 5 & 22 & 11 & 38 \\
\hline D & 7 & 16 & 17 & 40 \\
\hline E & 5 & 9 & 10 & 24 \\
\hline F & 3 & 11 & 4 & 18 \\
\hline G & 13 & 16 & 29 & 58 \\
\hline H & 7 & 13 & 7 & 27 \\
\hline
\end{tabular}

とって熟練度の違いか読み取りやすいクラスタが得られ たり，といった効果を期待して，実験協力者は辞書登録 を行うと想定し, 辞書に登録した単語数が多いほど, カ ルテ分析に有効であったと考える .この観点から比較す ると，今回の実験においては C-value と FLR で性能に大 差なかったと考えられる .

図 8 に, 各候補語について, 弚の語を辞書に追加した 実験協力者数をヒストグラムとして示す. 合計 192 語が 協力者に提示され，半数の 4 名以上が辞書に追加した候 補語は 41 語であった . 7 名が辞書に追加した候補語は 「腹部膨満」「退院指導」「血管造影」「化学療法」「ナー スコール」,8名全員が追加した候補語は「体位变換」, 「意識レベル」であった「意識レベル」に関しては，実 験協力者 $\mathrm{H}$ より「レベル」という語は解釈が樣々に可能 であるとの指摘があり，「意識レベル」を登録することで 意味を明確化することを期待したと考える．他に特徵的 な候補語として「キロサイド」があり，4 名が辞書に追 加している．この候補語は「キロ」と「サイド」の複合

$* 2$ 実際は, とロの間に全角空白 27 個が入るが , スペースの都 合上短縮している。 


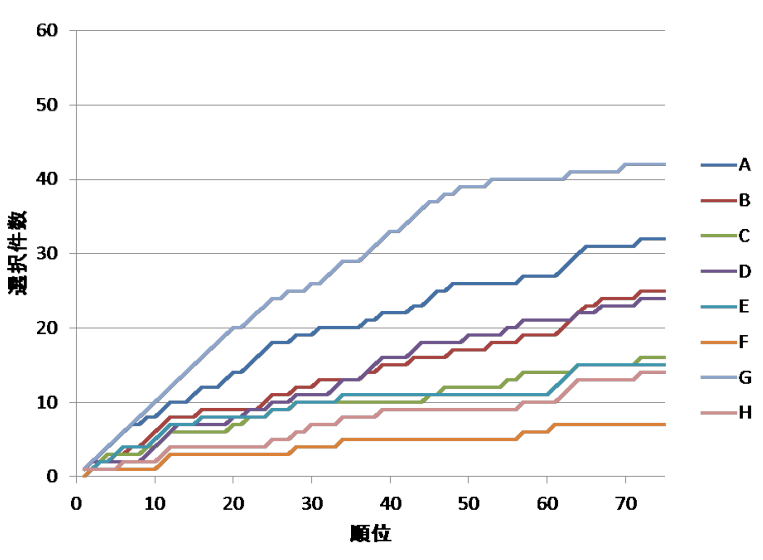

図 6 CValue の出力と辞書追加件数の関係

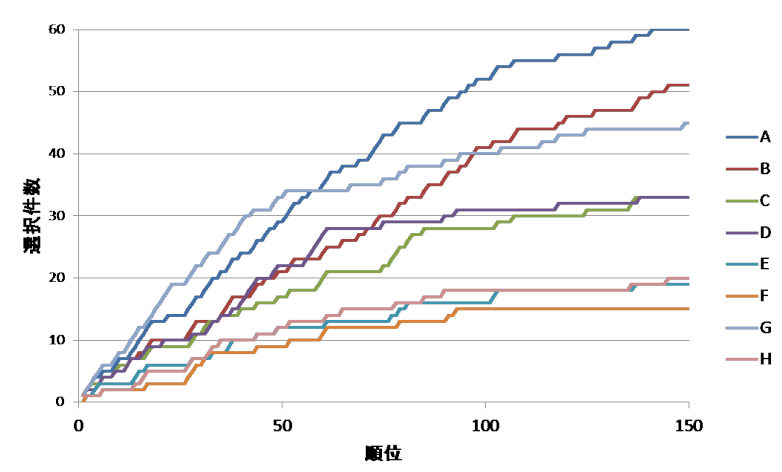

図 7 FLR の出力と辞書追加件数の関係

語であり，実験協力者 $\mathrm{A} ， \mathrm{~B} ， \mathrm{H}$ は「キロ」の意味が不 明あるいは暧昧と指摘しており， $\mathrm{C}, \mathrm{E}$ は略語と勘違い していた . 図 9 に、「キロサイド」を辞書に追加前後の力 ルテマップ (拡大図) を示す .なお，これは実験中のス クリーンショットではなく、「キロサイド」一語のみを追 加した場合のマップの違いを比較するために作成したも のである「・キロサイド」は抗がん斉の一種であり，辞書 に追加することで正しい分析・解釈が可能になったとい う意見があった . 以上より，提案の辞書構築支援ツール の利用方法として, 既存研究でも指摘されている単語の

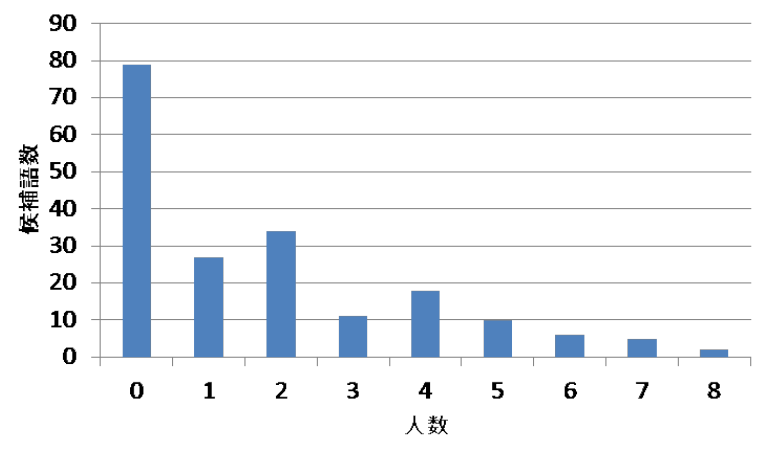

図 8 辞書追加を行った実験協力者数のヒストグラム
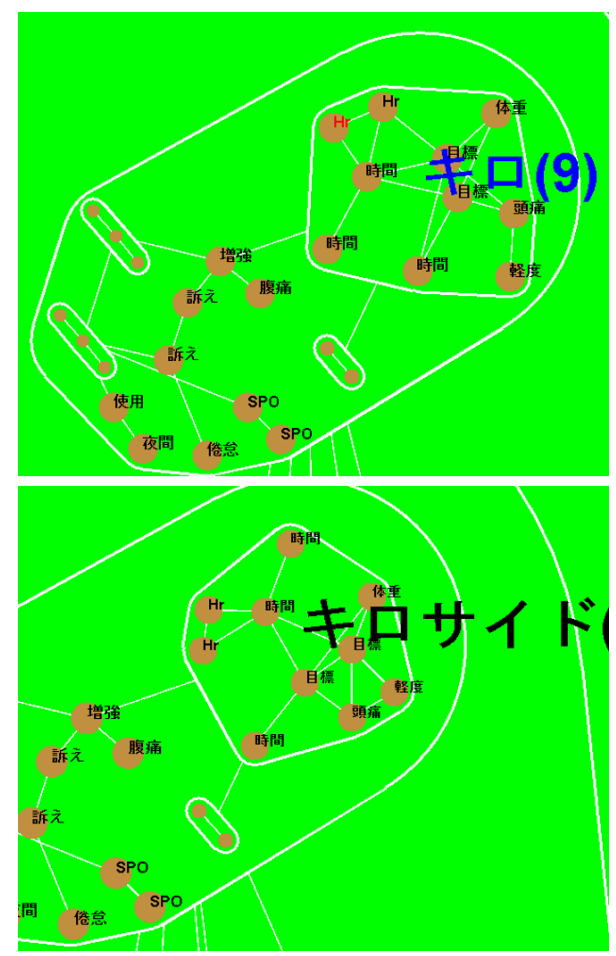

図 9 単語の辞書登録による効果の例：(上)「キロサイド」追加 前, (下) 追加後

表 4 新人作成のカルテの特徵

\begin{tabular}{|l|l|l|}
\hline 特徵 & 協力者 & 着目単語 \\
\hline あいまいな言葉が多い & $\begin{array}{l}\mathrm{A}, \mathrm{B}, \mathrm{D}, \\
\mathrm{E}, \mathrm{H}\end{array}$ & $\begin{array}{l}\text { キロ , サイド }, \\
\text { クリア, ルート }, \\
\text { 上記 , } \mathrm{BP}, \mathrm{Bp}\end{array}$ \\
\hline $\begin{array}{l}\text { 観察 , 測定したものを } \\
\text { そのまま载している }\end{array}$ & $\mathrm{B}, \mathrm{D}, \mathrm{F}$ & $\begin{array}{l}\mathrm{kg}, \mathrm{Wt}, \mathrm{CV}, \\
\mathrm{BP}, \mathrm{SpO} 2, \text { 低下 }, \\
\text { カニューラ, トイレ }\end{array}$ \\
\hline $\begin{array}{l}\text { 具体的でない・詳細が } \\
\text { 記入されていない }\end{array}$ & $\mathrm{C}, \mathrm{D}, \mathrm{E}$, & $\begin{array}{l}\text { トラブル, 不良 }, \\
\text { 少量 , 安定 }\end{array}$ \\
\hline
\end{tabular}

過分割の問題 [川中 05] を解決する他,「意識レベル向上」 の樣にコンテクストを含めることによる意味の明確化に も利用されたことがわかる .

\section{$4 \cdot 3$ 電子カルテ分析結果}

本節では，提案ツールを用いた電子カルテ分析結果に ついて，医療従事者である実験協力者からのコメントに 基づき考察する . 二人以上の実験協力者により指摘され た，新人作成のカルテの特徵，および各特徵に関して着 目された単語を表 4 , ベテラン作成のカルテの特徵およ び着目単語を表 5 に光れとめる. 表中の「協力者」 は，弚の特徵を指摘した協力者を表す。

表 4 , 表 5 に示した各着目単語を看護記録中で利用し た新人看護師，ベテラン看護師の人数を調べ，散布図に したものを図 10 に示す. 図中, 青色の単語は新人の着目 
表 5 ベテラン作成のカルテの特徵

\begin{tabular}{|l|l|l|}
\hline 特徵 & 協力者 & 着目単語 \\
\hline $\begin{array}{l}\text { 他者とのつながり, } \\
\text { 医師とのやりとり }\end{array}$ & $\begin{array}{l}\mathrm{A}, \mathrm{D}, \mathrm{E} \\
\mathrm{F}, \mathrm{G}\end{array}$ & $\begin{array}{l}\text { 依頼, 当直, 医師 } \\
\text { 母親, 家族 }, \\
\text { 報告, Dr. }\end{array}$ \\
\hline $\begin{array}{l}\text { 状態を表す記載 } \\
\text { が多い }\end{array}$ & $\mathrm{A}, \mathrm{B}$ & 発熱, 閉眼, 排尿 \\
\hline $\begin{array}{l}\text { 管理・安全など症状 } \\
\text { 以外の事が書いてある }\end{array}$ & $\mathrm{D}, \mathrm{F}, \mathrm{G}$ & 管理, 確認 \\
\hline
\end{tabular}

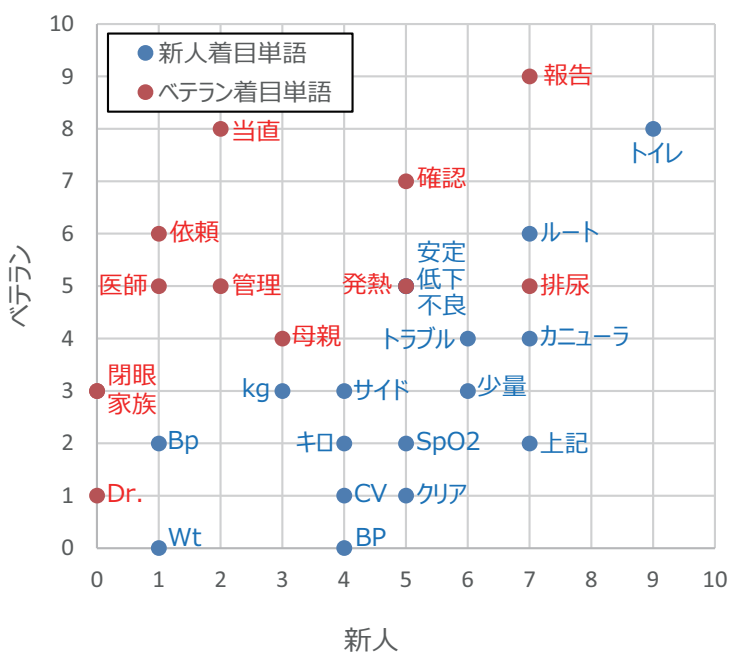

図 10 着目単語の利用に関する新人・ベテランの比較

単語，赤字はべテランの着目単語である. 横軸は光の単 語を使用した新人看護師，縦軸はべテラン看護師の人数 である．图より，新人 (ベテラン) の看護記録に特徵的 として着目した単語は, 新人 (ベテラン) の看護記録に より多く出現しており, 実験協力者は新人・ベテラン各 グループに弚れ午れ共通する単語に着目して分析を行っ ていることがわかる．また，利用した看護師が少ない単 語に Bp , Wt , Dr. があるが , データセット中での各単語 の出現頻度は乥れ光れ 7,6,3 回で, 着目単語の平均出 現頻度 22.9 回と比較して少ない . 従って, 実験協力者は 特定の看護師ではなく新人・ベテラン各グループに光れ

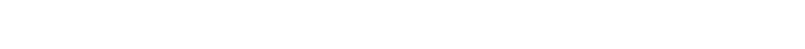
の実験では，看護師ごとの違いや特徵の分析は考慮して いないが，個人毎の看護記録データセットを作成し，同 樣の比較を行うことで可能と考える .

新人が作成したカルテに関して，表 4 にある「あいま いな言葉」に関しては，4.2 節に述べたように「キロ」， 「サイド」など形態素解析における問題も影響しており， この点に関しては辞書構築支援ツールを用いて単語を追 加した後に解決したものも存在する . しかし , 別のとこ ろに記載したものを「上記」として引用したり，BPなど の略語を使用していることなどが指摘された「観察，測
定したものを弚のまま記載している」とは, 測定した数 值を単に記載したり，見たものを弚のまま記載している だけであるなどの指摘を意味する .この他, 着目単語は 挙げられていないが, 患者の訴えを兴のまま記載してい るとの指摘もあった . 具体的あるいは詳細な記載がない 点については, 単にトラブルと書いてあるだけで, トラブ ルの内容について記載されていないなどの指摘があった .

これに対し，ベテランが作成したカルテに対しては， 医者 (医師) や家族など , 他者との関わりについての記 載があるとの指摘があった . また，関連する指摘として は，医師への報告や，指示内容の記載がされているとの 指摘があった . 新人との違いとして , 状態を表す記載が されているとの指摘があったが , 状態は患者に聞かない と記入できないとの意見もあった .これは, 単なるカル テ記載上の違いだけでなく，患者とのコミュニケーショ ンに関する新人とベテランの違いに関する気づきと考え られる.この他, 単に症状の記載ではなく, 安全面や管 理的視点からの記載もあるのが特徵的であるとの指摘も あった 。

上記を踏まえ，新人とベテランによるカルテの違いと して，以下の樣な意見が分析結果として得られた .

・新人は自分中心の記述が多いが, ベテランは他者と のつながりを意識している .

・新人は患者の訴えや計測値，観測したものを兴のま ま記載する傾向にある。

・新人は略語なども多く, 他者が見た時に統一した解 釈ができるようにとの配慮が足りない．

・ベテランは見たままでなく, 問題点や状態を明確に 記載している。

・ベテランは安全や管理面なども幅広く記載している．

・新人は任される範囲が少ないことも記載内容の違い につながっている可能性がある .

実験終了後にヒアリングを行ったところ，本実験で得 られた知見の中には，すでに知っていたこと，想像して いたことも含まれていたが，これまで気づいていなかっ た事も発見できたとの意見があった．実験に参加した医 師からは，「新人パターンの記述をしている職員に対し， ベテランパターンの記録を見せて教育する」や，「パター ンにより日々の経過記録を一つ一つ監査するのではなく， 一定期間分をまとめて効率よく監査する」といった応用 が可能との意見もあった．以上より，提案ツールにより 得られる分析結果は, 電子カルテの質的監査を行うとき のチェックポイントの検討や記入フォームの改善, カル テ作成の教育プログラムの検討などに活用可能と考える .

\section{4 利用者からの評価}

上記実験の協力者は医療従事者であり，自身で分析ツー ルを開発するスキルを持たない．また，電子カルテ分析 の必要性は感じていても，分析ツールの利用経験自体も ほとんどない，従って，TETDM か想定する利用者の分 
類 [砂山 14] における U-1 (PC が少し使えるがテキスト マイニングの知識, スキルのない人) あるいはU-2 (PC の扱いに慣れているがテキストマイニングの知識がない 人) に相当する. 光のような利用者の視点から, 提案ツー ル及び TETDM の利用可能性や課題について考察する .

TETDM は，マイニング処理だけでなく可視化処理も 統合している点がとつの特徴である.この点に関して， ただ単に記録文章として表示されたのでは読解に時間が かかるため活用困難であるが , 視覚的に表示されるのは わかりやすいという意見があり，提案ツールの表示方法 についても良好な意見が得られた . 具体的には, 可視化 により島としてまとまって提示されるキーワード群から， 前節で述べたようなカルテの特徽か読み取れるとの意見 があった . また , ツールの操作方法についてもわかりや すかったとの意見が得られた .

課題としては,「ディスプレイの表示画面を4つに分け て解析結果を表示するので結果を確認しにくい」ことが 指摘された . 現状では大画面ディスプレイという利用環 境か整備されていないという問題点があるが, 大画面ディ スプレイの低価格化は進んでおり，大学病院などでも急 速に導入されつつあるため, 近い将来解消することが期 待される.

また，PC 上で分析を行うだけでなく，印刷して議論し たいとの意見もあった . 今回の実験ではPC のみでの分 析作業としたが，TETDM はスクリーンショットを記録 する機能も備えているため分析結果の印刷は可能であり， 今後検討の価值があると考える .

今回の実験の範囲であれば, ツールの利用に関して特 に問題は指摘されなかったが，今後さらなる活用を考え た場合検討すべき課題も指摘された．すなわち，TETDM では多数の処理ッールや可視化ツールか提供されており， 利用するッール及び光の組み合わせを動的に変更可能で ある点が特色の一つであるが, ツールの組み合わせ方が わかりにくいという意見があった . 今回の実験では，利 用するパネルの組み合わせは固定し , パネルセット機能 を利用して提供しているため問題はなかったが, 医療現 場で利用者が自身の観点でッールを切り替えながら分析 を行うことは，現状では難しいと考えられる．この問題 に関して，利用方法を具体的に学べるチュートリアルの 必要性や, 医療用に機能を限定したバージョンの開発と いった案か提案された . 前者に関しては, TETDM のバー ジョン 0.53 からはチュートリアル機能を搭載しており， 今後も充実していくことが検討されている . 後者に関し ては，本実験で利用したパネルセット機能が有効であり， 今後電子カルテ分析に利用可能なツールの種類を増やし ていきながら，パネルセット機能により利用者にわかり やすい形式で機能提供することが可能と考える .

\section{5. ま と め}

本論文では，TETDM を利用した電子カルテ分析支援 ツールを開発し，実際の医師や看護師による実験を行っ て病院でのカルテ分析作業への適用可能性について検証 を行った . 提案ツールは電子カルテ分析支援ツールと辞 書構筑支援ツールから構成されており，TETDMによる 統一的なインタフェースで提供される. 実際の電子カル テデータを利用し，看護師の熟練度による電子カルテの 記述の違いを分析する作業を医師・看護師らに行っても

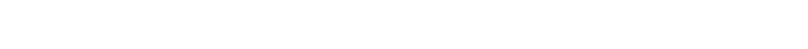
ルテの特徵や, 両者の相違点について有益な分析が行え ることを示した．また，辞書構築支援ツールを用いて単 語を追加することで, 単語の過分割の解消やコンテクス 卜の明確化が可能であり，カルテ分析に有効であること も示した。

今回の実験では,ツール開発者と利用者か別であり，両 者の連携により実施されたが , これは TETDM が目的と する「利用者と開発者が出会える場の提供」の一つのモ デルケースを示したとも言える.実験に参加した医師 , 看 護師からは TETDM を利用したツール提供に対し良好な 評価が得られており，今後より多樣な分析ツールを提供 し，連携を深めることが期待できる．また，看護師毎に データセットを作成し，同樣の分析を行うことで，各看 護師の記述の特徵を分析し, フィードバックするなどの 応用も今後の展望の一つとして考えられる .さらに , 今 回得られた意見を元にツールの機能および作業効率を向 上させること, ツールを TETDM のサイトで公開し，他 の病院などでも利用してもらうことも今後の課題である .

\section{$\diamond$ 参 考 文 献 $\diamond$}

[相澤 05] 相澤, 野末, 今, 坂本, 中渡瀬, 土木関連用語辞典の見 出し語の分析と検索システムにおける活用に関する考察,情報処 理学会研究報告/自然言語処理研究会報告 2005(94), pp. 131-138, 2005.

[Andrienko07] G. Andrienko, N. Andrienko, Coordinated Multiple Views: a Critical View, CMV'07, pp. 72 - 74, 2007.

[Ferrucci04] D. Ferrucci, A. Lally, UIMA: an architectural approach to unstructured information processing in the corporate research environment, Natural Language Engineering, Vol.10, No.3-4, pp.327 348, 2004.

[林 08] 林, 品川, 特徵語付きウェブ検索インタフェースの提案， DEWS2008 B5-6, 2008.

[東 05] 東，飛田，看護記録監査を基にした記録改善への取り組 み, 第 37 回看護研究発表論文集録, pp. 137 - 140, 2005.

[狩野 08] 狩野, 辻井, UIMA を基盤とする相互運用性の向上と 自動組み合わせ比較一国際共同プロジェクト U-Compare, 情報 処理学会自然言語処理研究会報告, Vol. 2008, No. 67, pp. $37-42$, 2008.

[狩野 12] 狩野，Kachako: 誰でも使える全自動自然言語処理プラッ トホーム, JSAI2012, 1B1-R -3 -3, 2012.

[川中 05] 川中, 大谷, 吉川, 山本, 篠木, 鶴岡, 自己組織化マッ プを用いた自由書式インシデント報告からの傾向発見に関する 一試み, 医療情報学, Vol. 25, No. 2, pp. 87-97, 2005.

[紀ノ定 03] 紀ノ定, 電子カルテ時代の医療情報学, 医療情報学, Vol. 23, No. 5, pp. 397-405, 2003.

[紀ノ定 06]紀ノ定,梅本, 猪口,武田，稲岡，マイニング技術を 
活用した定量的な診療プロセス分析への挑戦，医療情報学，Vol. 26, No. 3, pp. 191-199, 2006.

[厚労省 05] 厚生労働 省, 検討会における「看護 記録について」に関して出された主な意見 http://www.mhlw.go.jp/shingi/2005/10/s1017-12.html (2013 年 4 月 4 日現在)

[小山 06] 小山, 影浦, 竹内, 日本語専門分野テキストコーパス からの複合語用語の抽出，情報処理学会研究報告/自然言語処 理研究会報告 2006(124), pp. 55-60, 2006.

[久保 10] 久保, 辻, 杉本, 異なる学術分野のコーパスを利用し た専門用語抽出手法の提案, 情報知識学会誌, Vl. 20, No. 1, pp. 15-31, 2010

[松村 01] 松村, 電子カルテと病院情報システム，医療情報学， Vol. 21, No. 3, pp. 211-222, 2001.

[松村 12] 松村，1. 病院情報システム，黑田（監修），医療情報 システム，オーム社，pp. 1-16, 2012.

[村松 10] 村松, 渡部, 大崎, 小塚, 看護記録のテキストマイニング, 情報処理学会論文誌, Vol.3, No.3, pp. $112-122,2010$.

[元永 09] 元永, 末森, 藤井, 川石, 江本, 記録監査表からみた 精神科看護記録の現状の分析と改善への取り組み, 山口大学医 学部附属病院看護部紀要, Vol. 84, pp. $102-107,2009$.

[中川 03] 中川, 森, 湯本, 出現頻度と連接頻度に基づく専門用語 抽出, 自然言語処理, Vol. 10, No. 1, pp. $27-45,2003$.

[岡垣 11] 岡垣, 是垣, 中島, 和田 , 楠岡, 記載インターフェース の改良による電子カルテの記載の質と診療内容の質の变化 , 医 療情報学，Vol. 31, No. 1, pp. 37-48, 2011.

[砂山 12] 砂山，濱岡，奥田，情報收集のためのテキストデータ 集合の再帰的クラスタリング, 知能と情報, Vol.24, No.3, pp.697706, 2012

[砂山 14] 砂山, 高間, 西原, 梶並, 串間, 德永, 統合環境 TETDM を用いたマイニングッールの開発と利用の実践, 人工知能学会論 文誌, Vol. 29, No. 1, pp. 100-112, 2014.

[砂山 13] 砂山, 高間, 西原, 德永, 串間, 阿部, 梶並, テキストデー タマイニングのための統合環境 TETDM の開発, 人工知能学会 論文誌, Vol. 28, No. 1, pp. 1-12, 2013.

[砂山 11] 砂山, 高間, ダヌシカ, 西原, 德永, 串間, 松下, Total Environment for Text Data Mining, 人工知能学会論文誌, Vol. 26, No. 4, pp. 483-493, 2011.

[高橋 07] 高橋, 赤坂, 右川, 鶴田, 土橋, 目崎, 松嶋, 水越, 電 子カルテ導入が病院組織にもたらす効果について, 医療情報学, Vol. 27, No. 3, pp. 305-313, 2007.

[高間 13] 高間，阿部，テキストデータマイニング統合環境を 利用した看護記録からの専門用語辞書作成支援ツールの提案， JSAI2013，3B3-NFC-01b-1, 2013.

[高間 11] 高間, 狩野, 比較分析に着目した時空間的動向情報の探 索的分析支援，人工知能学会論文誌，Vol. 26, No. 4, pp. 494-503, 2011.

[谷 13] 谷, 砂山, 電子カルテにおける新人とベテランの特徵比 較支援システム, 第 3 回人工知能学会インタラクティブ情報ア クセスと可視化マイニング研究会, pp. 37-43, 2013.

[土井 09] 土井, 嶋田, 高崎, 鈴木, 藤田, 田村, 高林, 複数病 院間でのテキストマイニングによる DPC 判定の試み，第 13 回 日本医療情報学会春季学術大会, 2009 .

[辻河 04] 辻河, 吉田, 中川, 語彙空間の構造に基づく専門用語 抽出, 情報処理学会研究報告/自然言語処理研究会報告 2004(1), pp. 155-162, 2004

[上村 07] 上村, 喜田 , 有村, ウェブ閲覧における効率的なキー ワード抽出と关の利用, DBWeb2007, 2007.

[山本 07] 山本, 松本, 松葉, 多田, 松山, 柳原, 手良向, 福島, 電子カルテ二次利用臨床研究用データ収集システムの開発の展 望，医療情報学，Vol. 27, No. 2, pp. 211-218, 2007.

[山崎 13] 山崎, 酒田 , 鈴木 , 荒木 , 甲斐 , 教育用電子カルテを 用いた症例経営分析教育への試み，医療情報学，Vol. 33, No. 4, pp. 219-223, 2013.

[湯本 01] 湯本, 大畑, 森, 中川,語基の連接情報を用いた専門語抽 出, 言語処理学会年次大会発表論文集, Vol. 7, pp. 161-164, 2001.

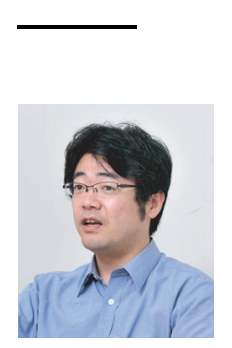

\section{紹}

高間 康史(正会員)

1994 年東京大学工学部電子工学科卒業. 1999 年同大学院 博士課程修了. 1999-2002 東京工業大学大学院総合理工学 研究科助手, 2002-2005 東京都立科学技術大学助教授, 2005 - 2014 首都大学東京システムデザイン学部准教授, 2014 年より同教授 . 博士 (工学) . Web Intelligence や情報可視 化, 知的インタフェースの研究に従事. 主要著書は「インテ リジェントネットワークシステム入門」(コロナ社) . IEEE， 学会各会員 日本知能情報ファジィ学会, 情報処理学会, 電子情報通信

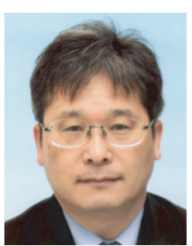

串間 宗夫(正会員)

1987 年宮崎大学大学院工学研究科修士課程修了. 2003 年 同大大学院工学研究科博士後期課程修了. 2012 年同大大 学院医学系研究科博士課程医学専攻修了. 宮崎大学医学部 附属病院研究員. 博士 (医学). 博士 (工学). 地方公務員 医学系では, 癌治療, 診療情報, 電子カルテ, 地域医療連 携, 工学系では, MOS アナログ集積回路, 多値論理回路, 教育工学，に興味をもつ。 日本医療情報学会，電子情報通 システム学会, 各会員 教育工学, に興味をもつ. 日本医療情報学会, 電子情報通
信学会, 多値論理研究会, ハハイイメ゙ィカル・ファジィ.

\section{砂山 渡(正会員)}

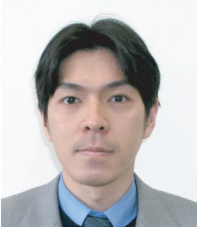

1995 年大阪大学基礎工学部制御工学科卒業. 1997 年同大 大学院博士前期課程修了. 1999 年同大大学院博士後期課 程中退. 同年同大学院助手, 2003 年広島市立大学助教授 2007 年同准教授, 現在に至る. 博士 (工学) . 人間の創造 活動を支援する研究に興味を持つ、電子情報通信学会、日 本知能情報ファジイ学会, 言語処理学会, IEEE, 各会員. 